\title{
PENINGKATAN KETERAMPILAN PARTISIPASI SOSIAL MELALUI PENDEKATAN PEMBELAJARAN KONTEKSTUAL DI SEKOLAH DASAR \\ Oleh: \\ Slamet Widodo ${ }^{1}$ \\ Universitas Negeri Surabaya
}

\begin{abstract}
The research was conducted on the basis of students' lack of social participation in the community. The cause of this situation is the lack of understanding of the students related to the importance of social participation skills. The purpose of this study was to describe the increase in the participation of students' social skills. The research design used classroom action research with data collection instruments, namely observation sheets, test sheets and questionnaire sheets. Data analysis technique used quantitative and qualitative. The research results showed that the participation of students' social skills improved through contextual learning approach.
\end{abstract}

Keyword: social studies, Learning Approach Contextual, Social Participation Skills.

\begin{abstract}
Abstrak: Penelitian ini dilaksanakan atas dasar partisipasi sosial siswa yang masih kurang di masyarakat. Penyebabnya adalah kurangnya pemahaman siswa terkait pentingnya keterampilan partisipasi sosial. Tujuan penelitian ini adalah untuk mendeskripsikan peningkatan keterampilan partisipasi sosial siswa. Desain penelitian menggunakan penelitian tindakan kelas dengan instrument pengumpulan datanya yaitu lembar observasi, lembar tes dan lembar angket. Teknik analisis data yang digunakan adalah kuantitatif dan kualitatif. Penelitian ini menunjukkan hasil bahwa keterampilan partisipasi sosial siswa meningkat melalui pendekatan pembelajaran kontekstual.
\end{abstract}

Kata Kunci: Pendidikan IPS, Pendekatan Pembelajaran Kontekstual, Keterampilan Partisipasi Sosial.

\section{PENDAHULUAN}

Hasil pengamatan peneliti selama mengajar memperlihatkan bahwa keterampilan sosial siswa masih rendah. Bukti nyata yang dapat diamati adalah ketika kelas atau sekolah melakukan kerja bakti membersihkan kelas tidak semua siswa ikut serta dalam kerja bakti tersebut. Siswa yang memiliki kesadaran saja yang melakukan kerja bakti, sedangkan siswa yang kurang memiliki kesadaran hanya bermain-main.

Siswa ketika piket kelas juga terlihat masih ada beberapa yang kurang peduli untuk membantu temannya yang membersihkan kelas. Dari wawancara pada siswa yang kurang berpartisipasi ternyata mereka malas. Tidak ada keinginan untuk gotong royong dan membantu temannya dalam melaksanakan piket kelas.

Tidak hanya pada kejadian itu saja, partisipasi siswa yang kurang ditunjukkan pada pembelajaran di kelas. Secara nyata siswa kurang kompak dan masih banyak siswa yang memiliki partisipasi dalam kerja kelompok. Siswa yang secara sadar dan paham tanggungjawabnya saja yang mengerjakan tugas. Sedangkan siswa yang partisipasi sosialnya rendah hanya ngikut nama. Ketika presentasi tugas kelompok di depan kelas, siswa yang hanya ngikut nama ketika ditanya tentang hasil pekerjaanya kurang menunjukkan jawaban yang tepat dan memuaskan.

Melihat kejadian secara nyata di sekolah, rendahnya keterampilan partisipasi sosial siswa disebabkan oleh; (1) guru belum mengembangkan pembelajaran yang dapat meningkatakan partisipasi sosial siswa, (2) guru belum mengembangkan strategi pembelajaran yang sesuai dengan perkembangan diri siswa, yang isinya mencakup model dan metode pembelajaran yang tepat, (3) guru

\footnotetext{
${ }^{1}$ Universitas Negeri Surabaya, Email: slamet.10050@gmail.com
} 
belum mengembangkan alur pembelajaran yang sesuai dengan model pembelajaran yang dipilihya, (4) guru belum mengembangkan keterampilan siswa secara khusus, artinya setiap keterampilan yang akan diajarkan kepada siswa membutuhkan model pembelajaran yang tepat, efektif dan efisien.

Kurikulum yang sekarang diterapkan pemerintah yaitu kurikulum 2013 memiliki pendekatan saintifik yang tidak lain adalah belajar dari menguraikan dan menyelesaikan masalah sehari-hari. Siswa diajak untuk menganalisis, mengamati, berhipotesis, menentukan penyelesaian dan kesimpulan. Dari keaktifan dalam menyelesaikan masalah seberanrnya membentuk siswa peduli dengan cara berpartisipasi. Maka sangat cocok bahwa siswa ditingkatkan partisipasi sosialnya mengikuti perkembangan kurikulum sekarang ini.

Sejatinya manusia merupakan makhluk sosial yang saling membutuhkan. Siswa yang sendiri tanpa memiliki teman pasti memiliki masalah. Apakah karena malas berteman ataukah kurang peduli dengan teman, bisa saja menjadi penyebabnya. Akan tetapi, kepedulian yang diwujudkan dengan berpartisipasi pada kesulitan yang dihadapi teman kelak akan kembali pada dirinya. Misalnya ada teman yang tidak membawa pensil karena lupa, karena teman yang satunya memiliki dua pensil, dipinjamkan kepadanya. Suatu saat teman yang membantu tadi jika menglami kesulitan maka akan dibantu juga. Oleh karena itu, sangat penting dalam menumbuhkan partisipasi sosial siswa.

Sesuai dengan permasalah tersebut peneliti perlu menentukan penyelesaian yang tepat. Peneliti memilih pendekatan pembelajaran kontekstual. Pemilihan solusi tersebut didasarkan oleh beberapa alasan, yakni; (1) pendekatan kontekstual sesuai dengan kurikulum yang berkembang saat ini, dimana pembelajaran sebenarnya merupakan penyelesaian dari masalah yang dihadapi sehari-hari, (2) pendekatan kontekstual sesuai dengan situasi dan kondisi tempat tinggal atau lingkungan sekitar siswa, siswa akan belajar dari masalah yang terjadi di lingkungan sekitar tanpa harus mencari-cari masalah yang belum pernah dialami siswa, (3) pendekatan kontekstual dapat dipadukan dengan model atau metode pembelajaran yang lainya sehingga topik yang bergantiganti pada setiap proses pembelajaran akan sangat membantu guru dengan penyesuaian materinya, (4) pendekatan kontekstual dapat membawa siswa pada situasi sebenarnya, apa saja yang harus dilakukan siswa terhadap perkembangan masalah yang terjadi di lingkungan sekitar.

Pemilihan pendekatan pembelajaran kontekstual tersebut juga didukung oleh penelitian atau pendapat yang relevan sebelumya. Rusman (2010:187) mengemukakan inti dari pendekatan kontekstual atau CTL (Contextual Teaching and Learning) adalah keterkaitan setiap materi atau topik pembelajaran dengan kehidupan nyata. Pembelajaran sebenarnya usaha menyesuaikan permasalahan yang sedang berkembang dengan kebutuhan dan tingkat perkembangan siswa. Selain itu, Nurhadi (dalam Rusman, 2010:189) mengatakan bahwa pembelajaran kontekstual merupakan konsep belajar yang dapat membantu guru mengaitkan antara materi yang diajarkan dengan situasi dunia nyata siswa dan mendorong siswa membuat hubungan antara pengetahuan yang dimilikinya dengan penerapanya dalam kehidupan mereka sebagai anggota keluarga dan masyarakat.

Hal serupa juga disampaikan Johnson (dalam Rusman, 2010: 189), contextual teaching and learning enables students to connect the content of academic subject with the immediate context of their daily lives to discover meaning. It enlarges their personal context furthermore, by providing students with fresh experience that stimulate the brain to make new connection and consequently, to discover new meaning. Pembelajaran menggunakan pendekatan CTL akan membantu siswa 
menghubungkan materi yang diterima siswa dengan situasi dan kondisi lingkungan sekitar yang sebenarnya.

Tujuan penelitian ini adalah (1) untuk mendiskripsikan aktivitas guru melalui pendekatan CTL; (2) untuk mendeskripsikan aktivitas siswa melalui pendekatan CTL; (3) untuk mendeskripsikan peningkatan keterampilan partisipasi sosial siswa melalui pendekatan CTL; dan (4) untuk mendeskripsikan respon siswa.

Ilmu pengetahuan sosial di SD merupakan gabungan secara terpadu dari beberapa bidang ilmu sosial, gabungan dari pelajaran ekonomi, sosiologi, geografi dan sejarah. Intisari dari masing-masing ilmu diintregasikan menjadi satu ke dalam bentuk ilmu pengetahuan sosial. Bobot materinya disesuaikan dengan perkembangan kemampuan siswa pada tingat SD. (Skeel, 1995)

Hal serupa juga disampaikan oleh Djahiri dan Ma'mun (dalam Gunawan, 2011: 17), IPS atau studi sosial konsepkonsepnya merupakan konsep pilihan dari berbagai ilmu lalu dipadukan dan diolah secara dikdatis pedagogis sesuai dengan tingkat perkembangan siswa. Artinya bahwa penekanan dari ilmu pengetahuan sosial yang diajarkan siswa merupakan ringkasan dan gabungan dari cabag-cabang ilmu sosial.

Pada tahun 1993 NCSS (National Council for the Social Studies) (dalam Sapriya, 2012:10) memaparkan "social studies is the integrated study of the social sciences and humanities to promote civic competence. Within the school program, social studies coordinated, systematic study drawing upon such disciplines as anthropology, archeology, economic, geography, history, law, philosophy, political science, psychology, religion and sociology as well as appropriate content from the humanities, mathematic and natural science. The primary purpose of social studies is to help young people develop to ability to make informed and reasoned decision for the public good as citizens of a culturally diverse, democratic society in an interdependent world."

Tujuan pendidikan IPS (Ilmu Pengetahuan Sosial) adalah membentuk warganegara yang baik, peduli terhadap sosial lingkunganya, membentuk manusia memiliki keterampilan dan kemampuan dalam menyelesaikan masalah sosial masyarakat serta memiliki norma dan nilai yang mampu menunjukkan manusia ke dalam kehidupan yang harmonis dan selaras dengan kehidupan sosial masyarakat.

Selaian itu, pendidikan IPS bertujuan membentuk manusia yang memiliki ilmu pengetahuan yang komprehenship yang terdiri dari gabungan ilmu hukum, ekonomi, sosiologi, antropologi, arkeologi, psikologi, sejarah, geografi, ilmu politik, dan agama guna membekali dalam menyelesaikan masalah dalam kehidupan sehari-hari. (Sardjiyo. Dkk, 2009)

Pendekatan pembelajaran kontekstual atau CTL merupakan usaha dan cara yang dipilih guru untuk mengajarkan pelajaran yang menghubungkan materi pelajaran dengan situasi nyata dalam kehidupan. (Suryanti, 2008) Konsep dan materi pelajaran diarahkan untuk menyesuaikan dengan hal-hal kehidupan langsung yang terjadi di kehidupan nyata. Penekanannya, siswa diajak untuk melihat secara nyata bagaimana menghubungkan keterkaitan ilmu pengetahuan dengan kehidupan nyata di dunia.(Trianto, 2010)

Nurhadi (dalam Rusman, 2010:190) berpendapat bahwa pembelajaran kontekstual (Contextual Teaching and Learning) merupakan konsep belajar yang dapat membantu guru mengaitkan antara materi yang diajarkan dengan situasi dunia nyata siswa dan mendorong siswa membuat hubungan antara pengetahuan yang dimilikinya dengan penerapan dalam kehidupan mereka sebagai anggota dan masyarakat. Pendekatan pembelajaran kontekstual akan menciptakan situasi belajar yang sesungguhnya dalam kehidupan nyata, sehingga masalah sosial akan dapat diselesaikanya dengan baik. 
Kelebihan pendekatan pembelajaran kontekstual dapat digabung dengan model dan metode pembelajaran yang relevan degan materi pembelajaranya.(Julianto, 2011) Guru dapat mengatur situasi pembelajaran sesuai dengan kreativitas dan inovasinya. Melalui pendekatan pembelajaran kontekstual suasana pembelajaran akan lebih menarik, siswa menjadi bersemangat karena di dalamnya akan membangun pengetahuan siswa secara teratur.

Kegiatan siswa akan semakin aktif, siswa melakukan penemuan, penyelidikan terhadaap masalah, siswa akan meniru secara langsung bagaimana berpartisipasi sosial yang baik. Sejalan dengan hal tersebut, Rusman (2010:191) menyebutkan ciri khas dari pendekatan pembelajaran kontekstual, yakni; 1) Constructivism, 2) Inquiry, 3) Questioning, 4) Learning Community, 5) Modelling, 6) Reflection, 7) Authentic Assessment. Karena ada pemodelan diharapkan siswa akan mampu meniru dengan baik, bagaimana siswa seharusnya berbuat sesuai dengan pemahaman pemodelan tadi. Sedangkan untuk mengukur sejauh mana ketercapaian siswa dalam pembelajaran, maka menggunakan penelaian secara langsung baik selama proses pembelajaran ataupun setelah selesai pembelajaran secara langsung.

Struktur pembelajaran kontekstual yakni; 1) melakukan hubungan yang berarti dengan kehidupan nyata, 2) melakukan kegiatan yang bermanfaat, 3) menentukan kegiatan belajar yang sesuai, 4) melakukan penggabungan dan diskusi antara materi dengan kenyataan, 5) menumbuhkan sikap dan keterampilan berpikir kritis, kreatif dan logis, 6) melakukan pembimbingan mandiri secara merata, 7) melakukan usaha yang maksimal sesuai indikator standarnya, 8) melakukan penilaian dan evaluasi.

Belajar dengan pendekatan pembelajaran kontekstual memiliki tujuh prinsip yang perlu dikembangan dalam pembelajaran. 1) konstruktivisme, konsep dan pengetahuan dibangun dengan cara sedikit demi sedikit secara teratur. Ilmu tidak hanya sebatas deretan teori yang dihafal, lebih dari itu ilmu mampu dibangun dengan pemahaman yang baik. kemudian mengaitkan dalam kehidupan nyata sehari-hari. 2) inkuiri, dalam pembelajaran siswa diajak untuk melihat masalah secara langsung, menganalisis masalah, menentukan rumusan masalah, menentukan hipotesis, memilih penyelesaian yang tepat, dan kesimpulan. Sesuai dengan sikap ilmiah ilmu pengetahuan, dari inkuiri siswa akan terbiasa menyelesaikan masalah yang dihadapinya dengan baik, berututan secara teratur sesuai tahapanya. 3) bertanya, bertanya merupakan kesempatan untuk berpikir kritis bagi siswa. Sangat penting memberikan pertanyaan pada siswa gunanya untuk menunjukkan seberapa tingkat pemahaman yang dikuasai siswa. 4) masyarakat belajar, adalah menumbuhkan kebiasaan siswa dalam kelas untuk menciptakan siswa yang suka belajar. Kegiatan ini dapat dilakukan dengan berdiskusi kelompok, tukar pendapat dan ide, ataupun pengalaman. Mengangkat permasalahan di lingkungan sekitar untuk didiskusikan di kelas. 5) pemodelan, merupakan memberikan contoh secara langsung yang disesuaikan dengan situasi lingkungan sekitar. Pemodelan bertujuan menunjukkan sikap, cara, nilai, perbuatann, ataupun tanggapan yag harus dilakukan siswa ketika berada di lingkungan masyarakkat. Tidak terkecuali bisa dilakukan di kelas atau lingkungan sekolah. 6) refleksi, merupakan usaha untuk berpikir kembali terhadap kegiatan belajar yang telah dilakukan. Guru bersama siswa melakukan refleksi dengan tujuan mengecek, menilai, memberikan pengutan atau penekanan, sehingga dari proses belajar yang dilakukan dapat dievaluasi, apa yang kurang bisa disiapkan pada pembelajaran selanjutnya. 7) penilaian autentik, merupakan aktivitas mencatat, mencermati, dan mendokumentasikan untuk mengetahui kualitas belajar siswa. Tingkat pemahaman dan ketercapaian 
dalam belajar dapat ditentukan dengan indikator yang telah ditetapkan. (Wahab, 2009)

Keterampilan partisipasi sosial merupakan kemampuan siswa yang sudah mahir dan sudah terbiasa dalam dalam rangka menumbuhkan rasa kepedulian dan kepekaan terhadap masalah-masalah sosial. (Muijs, 2008). Tanpa disuruh pun ketika siswa mengetahuinya bahwa hal tersebut membutuhkan partisipasi sosial maka akan dengan sendirinya siswa berpartisipasi. Tujuan keterampilan partisipasi sosial adalah menciptakan sikap dan perbuatan untuk menyelesaikan masalah sosial. Membangun masyarakat yang saling memiliki sifat kerukunan, kekompakan dan tanggap dalam menyelesaikan masalah sosial.

Keterampilan partisipasi sosial bagi siswa adalah menyelesaikan masalah sosial yang terjadi di sekitar siswa. Masalah tidak perlu mengambil yang di luar kemampuan siswa, tetapi cukup masalah yang sesuai dengan kemampuanya. Hal tersebut sejalan dengan Sapriya (2012:184) agar dapat aktif dalam kegiatan kemasyarakatan, para siswa tidak berarti harus serba tahu semua isu-isu atau persoalan kemasyarakatan. Namun, apa yang perlu dilakukan oleh siswa, paling tidak adalah dapat atau sebaiknya terlibat dalam setiap kegiatan untuk menjembatani kesenjangan apa yang dipelajari di sekolah dengan dunia nyata tempat para siswa itu berada.

Sesuai dengan pendapat tersebut maka sangat cocok bahwa keterampilan partisipasi sosial diajarkan dengan pendekatan pembelajaran kontekstual. Karena guru akan dapat menyesuaikan materi pelajaran dengan lingkungan sekitar tempat tinggal para siswa.

Pentingnya keterampilan partisipasi sosial adalah menumbuhkan jiwa gotong royong yang tidak akan pernah luntur walupaun kemajuan zaman. Masalah sosial yang tidak ada habisnya butuh penyelesaian dan kepedulian semua pihak.

Kegiatan partisipasi sosial dapat dilakukan mengikuti langkah sebagai berikut; 1) menentukan tujuan pembelajaran. Guru menyiapkan materi dan tujuan pembelajaranya sesuai dengan kebutuhan. 2) menyampaikan konsep pada siswa. Materi yang telah disusun guru disampaikan dalam kegiatan pembelajaran. 3) memilih masalah sosial yang sesuai. Guru bersama-sama siswa berdiskusi menentukan masalah sosial. 4) membuat langkah-langkah kegiatan. Guru bersamasama siswa meentukan langkah atau tahapan yang secara berurutan untuk dilakukan partisipasi sosial. 5) melakukan diskusi kelas. Guru menjaring aspirasi dan keinginan siswa dalam mewujudkan keterampilan partisipasi sosial. 6) melakukan persiapan alat, bahan, dan tempat, dan melakukan latihan. 7) melakukan kegiatan partisipasi sosial. Guru memandu jalanya praktek siswa, dan memberikan arahan yang sudah pernah dilatih secara bersama-sama. 8) membuat hasil laporan. Hasil dari praktek dibuat laporan sesuai dengan format yang telah ditentukan oleh guru. 9) melakukan refleksi dan evaluasi. Guru bersama siswa melakukan peninnjauan hal-hal apa saja yang kurang selama kegiatan. Saran dan perbaikan dilakukan secara bersama-sama. 10) penyimpulan. Guru membimbing siswa melakuan penyimpulan kemudian memberikan penekanan untuk dapat dilakukan dalam kehiduapan nyata.

\section{METODE PENELITIAN}

Desain penelitian ini menggunakan penelitian tindakan kelas. Terdiri empat tahapn pokok, yakni: (1) perencanaan (planning), (2) tindakan (acting), (3) pengamatan (observing), dan (4) refleksi (reflecting). Sesuai dengan tujuannya, bahwa penelitian tindakan kelas untuk meningkatkan belajar siswa khususnya meningkatkan keterampilan partisipasi sosial siswa.

Penelitian diadakan di SDIT Utsman Bin Affan yang terletak di Jln. Lakarsantri Selatan No. 33 Surabaya. Kelas yang dipilih adalah kelas 4 yang berjumlah 24 siswa. Penentuan lokasi penelitian ini 
adalah karena letak sekolah tersebut di kota Surabaya, melihat kondisi masyarakatnya memiliki keberagaman pekerjaan, latar belakang, dan kondisi sosial. Selain itu, dirasa para siswa sangat perlu dilatih pentingnya memiliki keterampilan partisipasi sosial mengingat masyarakat kota jiwa sosialnya tergolong rendah.

Teknik pengumpulan data yang digunakan adalah; 1) observasi, digunakan untuk mengetahui aktivitas guru dan siswa selama proses pembelajaran, 2) tes, digunakan untuk mengetahui seberapa tingkatan atau capaian keterampilan partisipasi sosial siswa, dan 3) angket respon siswa, digunakan untuk mengetahui respon siswa terhadap pembelajaran menggunakan pendekatan keterampilan partisipasi sosial siswa.

Sedangkan instrumen pengumpul data yang digunakan, yaitu (1) Lembar observasi, merupakan serangkaian urutan kegiatan dari awal pembelajaran sampai akhir pembelajaran yang digunakan untuk mengukur tingkat keberhaslan siswa dan guru; (2) Lembar tes, merupakan kumpulan soal yang mencerminkan keterampilan partisipasi sosial siswa, ketercapaian peningkatan keterampilan partisipasi sosial akan terlihat setelah mengetahui nilai tesnya; (3) Angket, berisi pernyataan siswa yang disebarkan setelah selesai kegiatan pembelajaran digunakan untuk mengetahui respon siswa selama mengikuti pembelajaran.

Teknik analisis data menggunakan analisis kualitatif dan kuantitatif. Data selama pembelajaran diamati oleh observer yang telah ditunjuk peneliti. Analisis hasil aktivitas guru dan siswa menggunakan rumus berikut ini:

$$
\mathrm{P}=\frac{f}{N} \times 100 \%
$$

dengan $\mathrm{P}$ merupakan presentase frekuensi kejadian muncul, $\mathrm{F}$ merupakan banyaknya aktivitas guru yang muncul, dan $\mathrm{N}$ adalah jumlah aktivitas kesseluruhan (Indarti, 2008:26)
Indikator keberhasilan penelitian ini adalah apabila siswa meningkat mencapai $\geq 80 \%$. Tingkat keberhasilan siswa dihitung dari siswa yang memperoleh nilai 80 mencapai $\geq 80 \%$ dikalikan seratus dihitung menggunakan rumus sebagai berikut:

$$
P=\frac{\sum x}{N} \times 100 \%
$$

dengan $\mathrm{P}$ adalah persentase, $\sum \mathrm{x}$ adalah jumlah siswa yang mendapatkan nilai $\geq 80$, dan $\mathrm{N}$ merupakan jumlah siswa seluruhnya.

Respon siswa diketahuai setelah pembelajaran dengan dibagikan angket. Pembelajaran dapat respon baik jika jawaban siswa yang menjawaba "ya" dikalikan seratus menggunakan rumus sebagai berikut:

$$
\mathrm{P}=\frac{f}{N} \times 100 \%
$$

dengan $\mathrm{P}$ merupakan presentase, $\mathrm{F}$ merupakan jumlah pemilih, dan $\mathrm{N}$ merupakan jumlah siswa keseluruhan (Indarti, 2008: 76).

Penelitian dikatakan berhasil jika memenuhi indikator berikut ini; 1) aktivitas guru dan siswa berhasil jika masing-masing aspek pembelajan dengan pendekatan pembelajaran kontekstual mencapai $\geq 80 \%$, 2) hasil keterampilan partisipasi sosial siswa meningkat jika siswa yag memperoleh nilai 80 mencapai presentasi $\geq 80 \%$, 3) hasil respon siswa dikatankan baik jika yang memilih kolom ya mencapai $\geq 80 \%$.

\section{HASIL DAN PEMBAHASAN Hasil Penelitian}

Dalam setiap siklus ada tahap yang selalu dilalui oleh peneliti, yaitu: (1) perencanaan, mempersiapkan keperluan pembelajaran dengan baik, yang dilakukan dengan kerjasama antara peneliti dengan guru seperti perangkat, media, dan pengaturan kelas; (2) pelaksanaan, kegiatan proses pembelajaran dengan pendekatan pembelajaran kontekstual; (3) pengamatan, 
dilakukan selama kegiatan pembelajaran berlangsung oleh observer yang telah ditentukan.; (4) refleksi, kegiatan melihat dan mengoreksi pembelajaran yang telah dilakukan, dilakukan bersama-sama antara peneliti dan observer.

Hasil aktivitas guru dalam pembelajaran antara siklus I sampai III dapat dilihat diagram berikut ini.

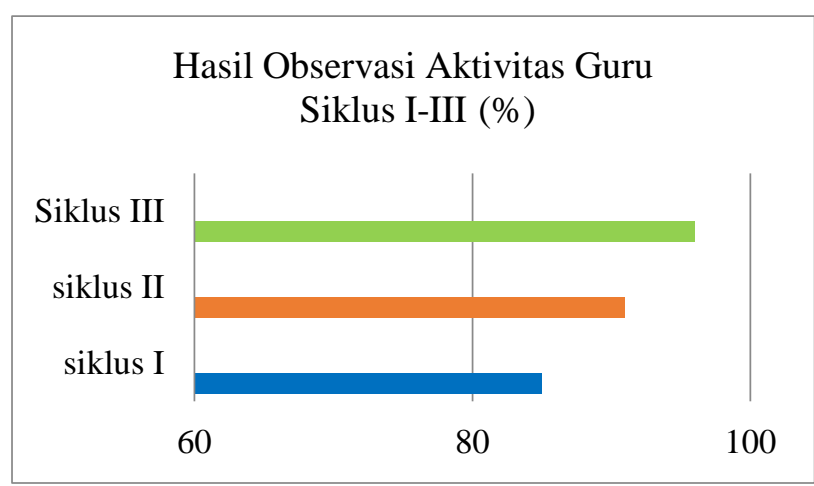

\section{Diagram 1: Hasil Observasi Aktivitas Guru Siklus I-III}

Hasil aktivitas guru dalam pembelajaran menggunakan pendekatan pembelajaran kontekstual sesuai diagram tersebut adalah siklus I memperoleh persentase sebesar 85\%, siklus II memperoleh persentase sebesar $91 \%$, dan pada siklus III memperoleh persentase sebesar 96\%. Dari setiap siklusnya telah mengalami peningkatan, sehingga penelitian berhenti pada siklus ke III.

Hasil aktivitas siswa selama pebelajaran menggunakan pendekatan pembelajaran kontekstual dapat diketahui pada diagram 2 berikut ini.

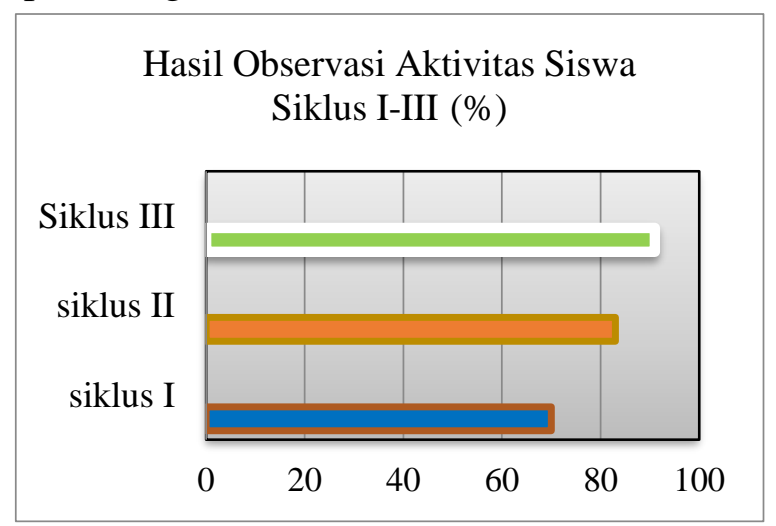

Diagram 2: Hasil Observasi Aktivitas Siswa Siklus I-III
Diagram tersebut menunjukkan hasil aktivitas siswa pada siklus I memperoleh persentase sebesar $70 \%$, siklus II sebesar 83\%, dan siklus III sebesar 91\%. Aktivitas siswa mengalami peningkatan pada setiap siklusnya. Hasil yang diperoleh sudah mencapai indikator yang ditetapkan, sehingga sampai siklus III aktivitas siswa dikatakan sudah baik.

Data hasil tes evaluasi siswa melaui pendekatan pembelajaran kontekstual dapat diperhatikan pada diagram 3 berikut ini.

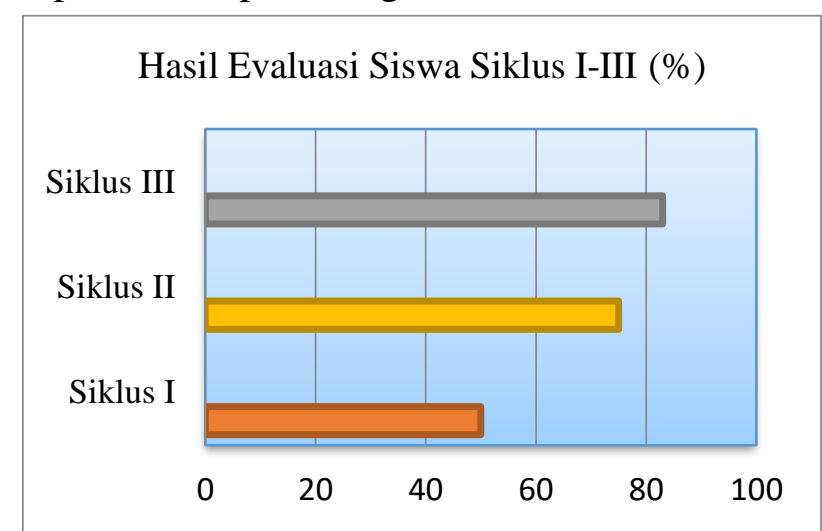

Diagram 3: Hasil Evaluasi Siswa Siklus I-III

Diagram hasil evaluasi siswa tentang keterampilan partisipasi sosial pada siklus I memperoleh persentase sebesar $50 \%$, siklus II sebesar 75\%, dan siklus III sebesar $83 \%$. Hasil yang diperoleh memperlihatkan bahwa keterampilan partisipasi sosial siswa selalu meningkat pada setiap siklusnya, penelitian sudah dinyatakan berhasil sampai pada siklus III.

Setelah dilakukan pembelajaraan menggunakan pendekatan pembelajaran kontekstual pada siswa kelas IV SDIT Utsman Bin Affan Lakarsantri memperlihatkan hasil yang sangat baik. Siswa merasa senang mengikuti pembelajaran, karena di dalamnya dilakukan simulasi atau praktek secara langsung bagaimana berpartisipasi sosial. Pembelajaran tidak hanya dilaksanakan dengan duduk dan mengerjakan soal-soal belaka, melainkan ada aktivitas yang menarik. 


\section{Pembahasan Penelitian}

Data pada diagram aktivitas guru menggunakan pendekatan pembelajaran kontekstual siklus I memperoleh persentase sebesar $85 \%$. Pada siklus I ada beberapa yang belum maksimal terletak pada aspek membimbing siswa dan pengondisian siswa. Dalam pembelajaran masih terlihat aktivitas yang masih di dominasi guru dan ada beberapa siswa yang masih ramai sediri. Siklus II memperoleh persentase sebesar 91\%. Pada siklus ini kegiatan guru lebih baik dari sebelumnya. Tetapi ada sedikit kesalahan yang dilakukan yaitu waktu yang seharusnya sesuai pada setiap aspeknya, ada beberapa aspek kegiatan yang kurang. Pada siklus III memperoleh persentase sebesar 96\%. Pada siklus ini guru sudah dinyatakan berhasil walupun masih ditemukan beberapa kekurangan tetapi tidak begitu berpengaruh dengan proses pembelajaran seperti ada penekanan dan refleksi yang begitu maksimal.

Setiap selesai siklus, peneliti berupaya mengevaluasinya dengan observer. Peneliti bersama observer melakukan analisis terhadap sesuatu yang telah dilakukan selama mengajar. Catatan dan hal yang telah dilakukan peneliti didiskusikan bersama untuk menentukan rencana pembelajaran selanjutnya.

Dalam penelitian ini ditemukan keuntungan, yakni; 1) pendekatan pembelajaran kontekstual dapat meningkatkan kepekaan sosial siswa, siswa menjadi lebih peduli terhadap perkembangan, situasi, dan kondisi lingkungan sekitarnya seperti membuah sampah pada tempatnya, menyiram tanaman dan lain-lain; 2) siswa merasa senang mengikuti pembelajaran dengan pendekatan pembelajaran kontekstual, hal ini terbukti siswa antuasias mengikuti simulasi langsung dalam pembelajaran; 3) pendekatan pembelajaran kontekstual menjadikan siswa lebih kritis terhadap permasalahan yang terjadi di lingkungan sekitar siswa.

Sebelum guru melakukan pembelajaran di kelas, guru harus benar- benar merencanakan dan mempersiapkan pembelajaran dengan matang, supaya proses pembelajaran dalam kelas juga didapat dengan maksimal. Terutama perangkat pembelajaran dan medianya. Manfaatnya hal-hal yang dirasa menjadi penghambat dapat diminimalisir sedini mungkin.

Selain itu, selama guru mengajar ada beberapa penghambat selama pembelajaran, yakni; 1) siswa terlalu terburu-buru dalam menangkap informasi dari guru, siswa banyak yang berebutan untuk bertanya sehingga kelas terkesan gaduh dan ramai, 2) pada saat pemodelan siswa kurang bisa tenang. Siswa menertawakan kesalahan yang dilakukan temanya sehingga kelas agak ramai.

Setelah melihat peningkatan aktivitas guru pada setiap siklusnya. Pendekatan pembelajaran kontekstual dapat meningkatkan kegiatan pembelajaran pada aktivitas guru.

Hasil aktivitas siswa pada siklus I memperoleh persentase sebesar 70\%. Hasil ini masih jauh dari harapan yang telah ditetapkan. Karena partisipasi sosial masih dianggap suatu hal yang baru bagi siswa. Siswa masih merasa bingung, mengkuti arahan guru. Dalam melakukan pemodelan masih banyak membutuhkan arahan guru. Hasil pencapaian siklus II sebesar $83 \%$. Aktivitas siswa pada siklus ini sudah menunjukkan peningkatan. Siswa sudah bisa mengikuti alur pembelajran yang diarahkan guru. Walaupun menunjukkan indikator keberhasilan masih dilanjutkan pada siklus selanjutnya, karena beberapa indikator belum terpenuhi. Sedangkan aktivitas siswa siklus III sebesar $91 \%$. Pada siklus III ini aktivitas siswa sudah sesuai indikator. Karena diikuti oleh keberhasilan pada aspek keterampilan partisipasi sosial siswa.

Aktivitas sosial menunjukkan peningkatan yang baik mulai dari siklus I sampai siklus III. Hal ini terjadi karena guru sudah mengevaluasi segala kekurangan pada setiap siklusnya. Penunjukkan peningkatan aktivitas siswa yang menonjol 
adalah pada saat pemodelan. Siswa antusias memberikan tanggapan, masukan, daan ide dalam menyelesaikan masalah yang telah ditunjukkan.

Selama proses pembelajaran menggunakan pendekatan pembelajaran kontekstual, ditemukan kelebihan dan keuntungan, yakni: siswa menjadi lebih bersemangat mengikuti pembelajaran. Siswa menjadi kritis terhadap isu dan permasalahan sosial. Dan siswa menjadi peduli dengan menunjukkan sikap dan perbuatan secara langsung apa yang harus diperbuat langsung.

Selama kegiatan pembelajaran berlangsung ada kendala yang dihadapi siswa, diantaranya yaitu; 1) terjadi kegaduhan pada saat pembentukan kelompok, siswa ribut dan ramai sendiri saat mencari kelompoknya. Hal ini disebabkan siswa kurang memperhatikan instruksi yang diberikan oleh guru, 2) siswa banyak mengajukan pertanyaan sehingga kesan kelas menjadi ramai, 3) guru perlu membimbimbing siswa satu per satu untuk memberikan pengarahan dan pemahaman terhadap siswa yang agak sulit memahami soal evaluasi.

Data hasil evaluasi siswa peningkatan keterampilan partisipasi sosial pada siklus I memperoleh persentase sebesar 50\%. Pada siklus I keterampilan partisipasi sosial siswa masih belum terlihat baik. Siswa masih belum terbiasa untuk tanggap dalam mendeskripsikan peran sosial. Siswa masih belum tahu apa yang seharusnya dilakukan ketika melihat kejadian sosial di masyarakat. Pada siklus II sebesar $75 \%$. Tahap ini mengalami peningkatan daripada sebelumnya. Khususnya pada tahap pemodelan sebelumnya siswa sudah dipersiapkan dengan matang. Sedangkan hasil siklus III sebesar $83 \%$. Hasil tes keterampilan partisipasi sosial siswa sudah dianggap tuntas. Hasil yang dicapai sudah mencapai indikator yang telah ditetapkan.

Hal dan aktivitas yang utama yang paling terlihat selama pembelajaran adalah; 1) siswa semakin tanggap dan peka terhadap permasalahan sosial, 2) siswa menjadi lebih aktif karena menganalisis masalah sosial untuk mencari penyelesaianya, 3) siswa menunjukkan sikap yang benar dalam berpartisipasi sosial, 4) siswa menunjukkan argumen yang kritis sesuai dengan konteks masalahnya.

Walaupaun hasil keterampilan partisispasi sosial siswa menunjukkan peningkatan, tetapi juga masih ditemukan kekurangan, yakni 1) siswa masih banyak yang belum paham dalam sikap yang harus diambil terhadap masalah sosial. Untuk solusinya guru memberikan bimbingan secara intensif pada siswa, 2) ada beberapa siswa yang kurang berminat terhadap pembelajaran yang akhirnya malah membuat ramai. Penyelesainya siswa disuruh duduk terpisah dengan teman yang sesama ramai seperti di depan dekat guru, 3) pada saat siswa sudah mulai jenuh siswa justru bermain-main, penyelesainya guru memberikan game ringan.

Respon siswa pada siklus ketiga menunjukkan hasil yang baik. Dari beberapa inovasi yang dilakukan dalam kelas, guru dapat menguasai kelas dengan baik. Siswa sangat tertarik dan senang mengikuti pembelajaran, karena secara langsung siswa dapat terlibat dalam masyarakat. Terbukti dari keaktivan siswa dalam mengikuti pembelajaran. Siswa dapat memeberikan argumen yang sesuai dengan permasalahanya. Siswa dapat mengikuti simulasi partisipasi sosial dengan baik. Siswa dapat mempresentasikan hasil analisis sosial di depan kelas dengan dipandu guru.

Catatan yang terpenting dalam peningkatan keterampilan partisipasi sosial melalui pendekatan pembelajaran kontekstual adalah terletak pada kreatvitas dan perencanaan guru. Guru harus dapat menyesuaikan materi pembelajaran dengan konteks kehidupan siswa. Selain itu, untuk menciptakan suasana kelas yang kondusif, guru harus cekatan dalam membuat keputusan. Supaya suasana kelas sesuai dengan sintaks pembelajaranya. 


\section{KESIMPULAN}

Kegiatan mengajar guru melalui pendekatan pembelajaran kontekstual menunjukkan hasil yang meningkat. Dibuktikan dengan hasil siklus I memperoleh persentase sebesar $85 \%$, siklus II memperoleh persentase sebesar $91 \%$, dan pada siklus III memperoleh persentase sebesar $96 \%$. Kegiatan yang paling baik adalah saat menjelaskan materi dan refleksi pemodelan. Guru dapat menguasai kelas dengan baik dengan game ringan yang menarik.

Melalui pendekatan pembelajaran kotekstual siswa menunjukkan aktivitas yang aktif, sesuai dengan urutan pembelajaran, dan kritis. Hasil penelitian meningkat pada setiap siklusnya. Siklus I memperoleh persentase sebesar $70 \%$, siklus II sebesar $83 \%$, dan siklus III sebesar $91 \%$. Hal yang paling terlihat adalah siswa sangat antusias mengikuti pemodelan dan inkuiri, karena siswa dapat menganalisis masalah sosial dalam rangka menunjukkan sikap ppaertisipasi sosial dan menentukan penyelesaian yang tepat.

Keterampilan partisipasi sosial siswa melalui pendekatan pembelajaran kontekstual mengalami peningkatan. Siswa dapat memberikan ide penyelesaian yang sesuai dengan masalah. Siswa bersemangat melakukan pemodelan dan prkatek secara langsung. Hal tersebut dibuktikan dengan pemerolehan hasil tes keterampilan partisipasi siswa. Siklus I memperoleh persentase sebesar $50 \%$, siklus II sebesar $75 \%$, dan siklus III sebesar $83 \%$.

Siswa merasa senang mengikuti pembelajaran. Hal inilah yang menunjukkan respon pembelajaran baik. Siswa merasa kegiatan pembelajaran lebih menantang karena harus menyelesaikan masalah sosial di masyarakat.

Supaya pembelajaran berjalan dengan lancar, guru harus mempersiapkan pembelajaran dengan baik, perangkat pembelajaran, materi, lembar evaluasi, media, dan penilaianya. Guru harus menguasai materi sebelum diajarkan kepada siswa. Mengantisipasi kelas yang ramai, guru harus memiliki cara atau usaha yang telah dipersiapkan sebelumnya.

Untuk menciptakan kelas yang efektif guru harus memilih permasalahan sosial yang sesuai dengan lingkungan sekitar dan kemampuan siswa. Masing-masing aspek pembelajaran dilakukan secara seimbang, khususnya pada saat pemodelan siswa ditekankan untuk turut serta pembelajaran. Guru harus menciptakan suasana kelas yang menyenangkan.

Usaha untuk mendukung kompetensi guru agar lebih maksimal. Guru dapat membaca dan memahami lingkungan sekitar siswa. Membaca buku, majalah, media masa dalam rangka menambah wawasan masalah sosial masyarakat. Sedangkan inovasi yang dapat dilakukan adalah dengan menggabungkan pengalaman siswa dengan keadaan lingkungan sekitar siswa.

\section{DAFTAR PUSTAKA}

Gunawan, R. (2011). Pendidikan ips filosofi, konsep, dan aplikasi. Bandung: Alfabeta.

Indarti, T. (2008). Penelitian tindakan kelas (ptk) dan penulisan ilmiah. Surabaya: Lembaga Penerbitan Fakultas Bahasa dan Seni Unesa.

Julianto. dkk. (2011). Teori dan implementasi model-model pembelajaran inovatif. Surabaya: Unesa University Press.

Muijs, D. dkk. (2008). Effective teaching teori dan aplikasi. Yogyakarta: Pustaka Pelajar.

Rusman. (2010). Model-model pembelajaran: mengembangkan profesionalisme guru. Bandung: Rajawali Press.

Sapriya. (2012). Pendidikan ips konsep dan pembelajaran. Bandung: PT Remaja Rosdakarya.

Sardjiyo. dkk. (2009). Pendidikan ips di sd. Jakarta: Universitas Terbuka.

Skeel, D. J. (1995). Elementary social studies challenges for tomorrow's world. United States of America: Harcourt Brace and Company. 
Suryanti. (2008). Model-model pembelajaran inovatif. Surabaya: Unesa University Press.

Trianto. (2010). Mendesain Model Pembelajaran Inovatif Progresif. Jakarta: kencana Prenada Media Group. Wahab, A. A. (2009). Metode dan modelmodel mengajar ilmu pengetahuan sosial. Bandung: Alfabeta. 